\title{
Protection of low-carbon steel in solutions of mineral acids by nitrogen-containing pharmaceutical agents of triphenylmethane series
}

\author{
Ya.G. Avdeev, ${ }^{1 *}$ E.N. Yurasova, ${ }^{2}$ K.L. Anfilov ${ }^{3}$ and T.A. Vagramyan ${ }^{2}$ \\ ${ }^{1}$ A.N. Frumkin Institute of Physical Chemistry and Electrochemistry, Russian Academy \\ of Sciences, Leninskii pr. 31, Moscow, 119071 Russian Federation \\ ${ }^{2}$ Dmitry Mendeleev University of Chemical Technology of Russia, Miusskaya sq. 9, \\ Moscow, 125047 Russia Federation \\ ${ }^{3}$ Bauman Moscow State Technical University (Kaluga Branch), Bazhenov str. 2, Kaluga, \\ 248000 Russian Federation \\ *E-mail: avdeevavdeev@mail.ru
}

\begin{abstract}
The corrosion of St3 steel in $2 \mathrm{M} \mathrm{HCl}, \mathrm{H}_{2} \mathrm{SO}_{4}$ and $\mathrm{H}_{3} \mathrm{PO}_{4}$ in the presence of nitrogencontaining pharmaceutical agents of the triphenylmethane series, viz., fuchsine, Malachite Green and Brilliant Green, as well as Methyl Violet with related structure, has been studied. Of the compounds studied, the highest steel protection is provided by Brilliant Green, which in mixtures with urotropine or KNCS inhibits steel corrosion in $\mathrm{HCl}, \mathrm{H}_{2} \mathrm{SO}_{4}$ and $\mathrm{H}_{3} \mathrm{PO}_{4}$ solutions at temperatures up to $95^{\circ} \mathrm{C}$. The high protective effect of the inhibitor formulations developed on the basis of Brilliant Green on steel corrosion in mineral acid solutions is a result of efficient inhibition of the electrode reactions on the metal by these compounds.
\end{abstract}

Key words: low-carbon steel, acid corrosion, corrosion inhibitors, pharmaceutical agents, Brilliant Green.

Received: December 4, 2017. Published: February 9, 2018

doi: $\underline{10.17675 / 2305-6894-2018-7-1-8}$

\section{Introduction}

Compounds of the triphenylmethane series are widely used in various areas of human activities. They are used as synthetic dyes, acid base indicators [1], and pharmaceutical agents [2]. Brilliant Green is a highly active and fast-acting antiseptic [2]. Fuchsine is an antifungal agent showing activity against staphylococci. Malachite Green and Brilliant Green find use in veterinary medicine against ichthyophthiriasis in fish farms [3]. These compounds are commercially available in sufficient quantities.

Many chemical compounds used in medicine are efficient inhibitors of metal corrosion in acids. It is enough here to remind about urotropine that has been used in medicine for over 100 years. It is the basis or a component of many inhibitors, including 
those produced on industrial scale [4]. It has recently been shown $[5,6]$ that multicomponent inhibitor formulations containing urotropine can slow down the corrosion of low-carbon and chromium-nickel steels in $\mathrm{HCl}$ and $\mathrm{H}_{2} \mathrm{SO}_{4}$ solutions under hightemperature corrosion conditions (up to $200^{\circ} \mathrm{C}$ ).

Corrosion scientists abroad are actively studying pharmaceutical agents as metal corrosion inhibitors, as indicated in reviews [7-9] that are predominantly of information character. It has been noted that the corrosion of steels in acid media is inhibited by

compounds belonging to $\beta$-lactams (penicillins

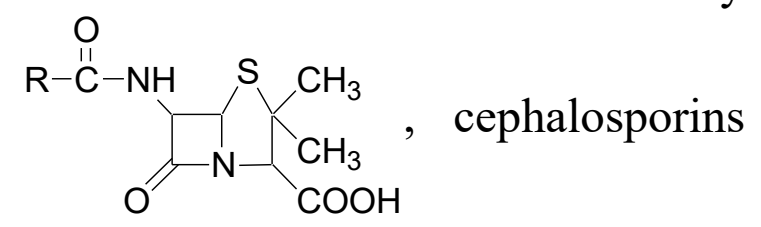

, antibiotics containing a quinoline moiety, sulfanilamide compounds $\mathrm{H}_{2} \mathrm{~N}-\mathrm{SO} \mathrm{S}_{2}-\mathrm{NHR}$, antiviral, antihistaminic and some other drugs. These compounds manifest inhibitory activity due to the various groups that they contain (heterocyclic systems, $\mathrm{N}, \mathrm{S}$ and $\mathrm{O}$ atoms), through which they are presumably adsorbed on a metal surface [7]. Analysis of the features of corrosion behavior of steels in acid media in the presence of various pharmaceutical agents shows that these compounds can be adsorbed on metals rather efficiently and that their adsorption predominantly obeys the Langmuir isotherm. In these cases, the free energy of adsorption on steel surface generally does not exceed $40 \mathrm{~kJ} / \mathrm{mol}$, which does not allow us to make unambiguous conclusions that they are chemisorbed on the metal [8].

Among penicillins, inhibitive effects on the corrosion of steels in $\mathrm{HCl}$ solutions are shown by Ampicillin [10], Cloxacillin [11], and Amoxicillin [12, 13], which cannot provide protective effects $Z>90 \%$ even in cold solutions. The potassium salt of Penicillin $\mathrm{V}$ [14], Cloxacillin [15], Amoxicillin [16], and Ampicillin [17] have similar low efficiency in $\mathrm{H}_{2} \mathrm{SO}_{4}$ solutions. The protective properties of Ampicillin can be improved by using it in combination with halide anions. At $t=50^{\circ} \mathrm{C}$, addition of $1.0 \mathrm{mM}$ Ampicillin to $0.1 \mathrm{M}$ $\mathrm{H}_{2} \mathrm{SO}_{4}$ provides $Z=66.9 \%$ on low carbon steel, while in the presence of $60 \mathrm{mM} \mathrm{KCl}, \mathrm{KBr}$ and $\mathrm{KI}$, the protection efficiency increases to $88.4,92.0$ and $76.6 \%$, respectively [17]. A higher steel protection in $\mathrm{HCl}$ is provided by cephalosporins, viz., Cefotaxime sodium salt [18], Cefazolin [19], Cefalexin [20], and Ceftazidime [21]. According to electrochemical impedance spectroscopy (EIS) data, Cefatrexyl can inhibit iron corrosion in $\mathrm{HClO}_{4}, \mathrm{H}_{2} \mathrm{SO}_{4}$ and $\mathrm{H}_{3} \mathrm{PO}_{4}$ [22]. A few antibiotics, namely, Ciprofloxacin (I), Norfloxacin (II), Ofloxacin (III) [23] and Gatifloxacin (IV) [24]: 
<smiles>CCn1cc(C(=O)O)c(=O)c2cc(F)c(N3CCNCC3)cc21</smiles>

efficiently hinder carbon steel corrosion in cold $\mathrm{HCl}$ solutions. It has been shown that a temperature $(t)$ rise decreases the inhibitory properties of Gatifloxacin [24]. Sulfanilamide compounds such as Sulfadiazine (V), Sulfamethoxazole (VI), Sulfamethazine (VII) and Sulfaguanidine (VIII)

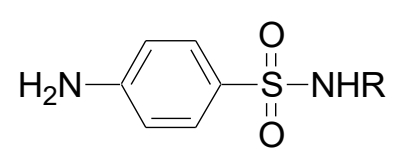

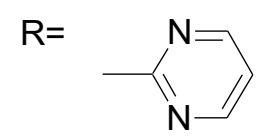

(V)<smiles>Cc1cc(C)on1</smiles>

(VI)<smiles>Cc1cc(C)nc(C)n1</smiles><smiles>CC(=N)N</smiles>

have been studied as inhibitors of low-carbon steel corrosion in $1 \mathrm{M} \mathrm{HCl}$ and $0.5 \mathrm{M} \mathrm{H}_{2} \mathrm{SO}_{4}$ $\left(25^{\circ} \mathrm{C}\right)$. According to gravimetric and electrochemical studies, their efficiency in inhibition of low carbon steel corrosion decreases in the series: V > VI > VII > VIII. Moreover, the inhibitors in question hinder corrosion in $1 \mathrm{M} \mathrm{HCl}$ much better than in $0.5 \mathrm{H}_{2} \mathrm{SO}_{4}$ [25]. The dependence of the protective effect of these sulfanilamides on their structure well correlates with the data of quantum-mechanical calculations performed for these molecules using the density functional theory and some semiempirical methods [26].

The feasibility of low carbon steel protection in cold $0.5 \mathrm{M} \mathrm{HCl}$ by vitamin $\mathrm{B}_{1}$ (thiamine, A) was studied.<smiles>Cc1ncc(C[n+]2csc(CCO)c2C)c(N)n1</smiles> 
It provides $Z=91.5 \%$ only at high $C_{\text {in }}(10 \mathrm{mM})[27,28]$. In sulfuric acid solutions, vitamin $\mathrm{B}_{12}$ (cyanocobalamine, $\mathbf{B}$ ) has low efficiency. According to voltammetry and EIS data, it can ensure low carbon steel protection only in combination with KI [29]. Barbituric acid derivatives
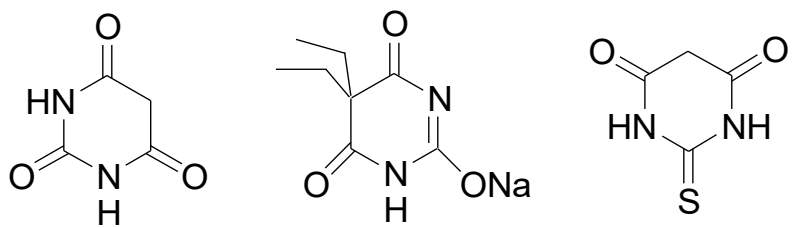

poorly inhibit low carbon steel corrosion in $1 \mathrm{M} \mathrm{H}_{3} \mathrm{PO}_{4}$. Only the latter compound can provide $Z>90 \%$ [30]. As we noted previously [31], this is characteristic of phosphoric acid media where efficient corrosion inhibition is shown by organic compounds containing S atoms.

The classification of pharmaceuticals that act as corrosion inhibitors based on their pharmacological action, as suggested in review [7] and used by us above, is not quite well justified in our opinion. It takes into account only the existence of physiologically active atom groups in the molecules and rather often joins together compounds of different classes, but the presence of these atom groups does not always determine their protective action on the corrosion of metals. It should be noted that the inhibitory activity of the pharmaceuticals considered above, many of which are quite expensive compounds, towards steels is observed in cold acid solutions and is often lost at higher temperatures. However, in practice, protection of metals requires inhibitors that remain efficient at temperatures at least up to $80^{\circ} \mathrm{C}$. Almost no. attention was paid to the opportunity to create composite corrosion inhibitors based on pharmaceuticals, which is among important approaches in the contemporary Corros. Sci. [32]. The viewpoint of G. Gece [7] that it is invalid to consider many pharmaceuticals, antibiotics in particular, as "environmentally friendly" corrosion inhibitors, deserves attention.

It seems worthwhile to develop efficient corrosion inhibitors for low carbon steel in mineral acid solutions with a broad temperature range, based on available pharmaceuticals such as fuchsine, Malachite Green and Brilliant Green belonging to amines of triphenylmethane series (Table 1). It is important to consider the feasibility of increasing the protective properties of these compounds by creation of composite inhibitors on their basis. For comparison, we studied Methyl Violet, a triphenylmethane derivative similar in structure to the pharmaceuticals being studied. 
Table 1. Structural formulas of the compounds studied.

\begin{tabular}{|c|c|c|c|c|}
\hline Derivatives of triphenylmethane & Structural formula & & $\begin{array}{c}\text { Molecular } \\
\text { formula }\end{array}$ & $\begin{array}{c}\text { Molar mass, } \\
\text { g/mol }\end{array}$ \\
\hline $\begin{array}{l}\text { Fuchsine (rosaniline hydrochloride) } \\
(4-[(4-A m i n o p h e n y l)(4-i m i n o-2,5- \\
\text { cyclohexadien-1-ylidene)methyl]-2- } \\
\text { methylaniline hydrochloride }(1: 1))\end{array}$ & & $\mathrm{Cl}^{-}$ & $\mathrm{C}_{20} \mathrm{H}_{20} \mathrm{ClN}_{3}$ & 337.8 \\
\hline $\begin{array}{c}\text { Methyl Violet 2B } \\
\text { (4,4'-[(4-Imino-2,5-cyclohexadien- } \\
\text { 1-ylidene)methylene]bis }(N, N- \\
\text { dimethylaniline) hydrochloride } \\
(1: 1))\end{array}$ & $\mathrm{H}_{3} \mathrm{C}^{\mathrm{N}} \mathrm{CH}_{3}$ & $\mathrm{Cl}^{-}$ & $\mathrm{C}_{23} \mathrm{H}_{26} \mathrm{ClN}_{3}$ & 379.9 \\
\hline $\begin{array}{c}\text { Malachite Green oxalate } \\
\left(N, N, N^{\prime}, N^{\prime}-\text { Tetramethyl-4,4'- }\right. \\
\text { diaminotriphenylcarbenium } \\
\text { oxalate })\end{array}$ & & & $\mathrm{C}_{26} \mathrm{H}_{27} \mathrm{~N}_{2} \mathrm{O}_{6}$ & 463.5 \\
\hline $\begin{array}{c}\text { Brilliant Green oxalate } \\
\left(N, N, N^{\prime}, N^{\prime}-\text { Tetraethyl-4, } 4^{\prime}-\right. \\
\text { diaminotriphenylcarbenium } \\
\text { oxalate })\end{array}$ & & $\mathrm{HC}_{2} \mathrm{O}_{4}^{-}$ & $\mathrm{C}_{29} \mathrm{H}_{35} \mathrm{~N}_{2} \mathrm{O}_{4}$ & 475.6 \\
\hline
\end{tabular}

\section{Experimental}

Solutions were prepared from mineral acids ("chemically pure" grade) and distilled water. The base concentration of individual organic inhibitors in acid solutions was $1.0 \mathrm{mM}$. Due to the low solubility of the triphenylmethane derivatives being studied, they were added as solutions in ethanol. The resulting ethanol concentration in the pickling solution did not exceed $1.2 \mathrm{~mol} / \mathrm{l}$.

The corrosion rate of steel was determined from the mass loss of specimens (at least three specimens per point) made of St3 ${ }^{*}$ steel with dimensions of $50.0 \mathrm{~mm} \times 20.0 \mathrm{~mm} \times$ $1.5 \mathrm{~mm}$, in $2 \mathrm{M} \mathrm{HCl}, \mathrm{H}_{2} \mathrm{SO}_{4}$ and $\mathrm{H}_{3} \mathrm{PO}_{4}$, using $50 \mathrm{ml}$ of the acid solution per specimen. The test duration was $2 \mathrm{~h}$ at $t=25-95^{\circ} \mathrm{C}$. Prior to the experiments, the St 3 steel specimens were cleaned on an abrasive disc (ISO 9001, 60 grit) and degreased with acetone.

The efficiency of the inhibitors was estimated from the inhibition coefficient, $\gamma=k_{0} / k_{\text {in }}$ and degree of protection $Z=\left[\left(k_{0}-k_{\text {in }}\right) / k_{0}\right] \cdot 100 \%$, where $k_{0}$ and $k_{\text {in }}$ are the corrosion rates in the non-inhibited solution and in the solution with the compound being studied, respectively. 
Electrochemical measurements were carried out on a static cylindrical electrode made of $\mathrm{St} 3$ steel $\left(0.3 \mathrm{~cm}^{2}\right)$ in naturally aerated $2.0 \mathrm{M} \mathrm{HCl}, \mathrm{H}_{2} \mathrm{SO}_{4}$ and $\mathrm{H}_{3} \mathrm{PO}_{4}$ solutions at $t=25^{\circ} \mathrm{C}$. The steel electrode potentials were measured against a silver chloride electrode and converted to the normal hydrogen scale. An electrode pre-cleaned with emery paper M20 and degreased with acetone was kept for $30 \mathrm{~min}$ in a solution being studied, then an EL-02.061 potentiostat was used to successively record anodic and cathodic polarization curves at a potentiodynamic sweep rate of $0.0005 \mathrm{~V} / \mathrm{s}$.

\section{Experimental results and discussion}

\section{Corrosion studies}

In $2 \mathrm{M} \mathrm{HCl}\left(t=60^{\circ} \mathrm{C}\right)$, addition of $1.0 \mathrm{mM}$ individual triphenylmethane derivatives slows down the corrosion of steel 10-19 fold (Table 2). The protective effect of the compounds studied decreases in the series: Brilliant Green $(B G)>$ Malachite Green $\approx$ Methyl Violet $2 \mathrm{~B}>$ fuchsine. It necessary to note that incorporation of alkyl radicals bound to amino groups into compounds with similar structures belonging to the triphenylmethane series enhances the protective effect of inhibitors. The observed effect is the higher, the longer the hydrocarbon radicals.

Table 2. Corrosion rates $(k)$ of St3 steel and corrosion inhibition coefficients $(\gamma)$ in 2 M solutions of acids in the presence of $1.0 \mathrm{mM}$ triphenylmethane derivatives $\left(60^{\circ} \mathrm{C}\right)$.

\begin{tabular}{cccc}
\hline Inhibitor & Acid & $\boldsymbol{k}, \mathbf{g} /\left(\mathbf{m}^{2} \cdot \mathbf{h}\right)$ & $\gamma$ \\
\hline \multirow{2}{*}{ Fuchsine } & $\mathrm{HCl}$ & 81 & - \\
& $\mathrm{H}_{2} \mathrm{SO}_{4}$ & 117 & - \\
& $\mathrm{H}_{3} \mathrm{PO}_{4}$ & 38 & - \\
& $\mathrm{HCl}$ & 8.1 & 10 \\
& $\mathrm{H}_{2} \mathrm{SO}_{4}$ & 55 & 2.1 \\
& $\mathrm{H}_{3} \mathrm{PO}_{4}$ & 48 & 0.79 \\
\hline \multirow{3}{*}{ Methyl Violet 2B } & $\mathrm{HCl}$ & 4.4 & 18 \\
& $\mathrm{H}_{2} \mathrm{SO}_{4}$ & 42 & 2.8 \\
Malachite Green & $\mathrm{H}_{3} \mathrm{PO}_{4}$ & 56 & 0.68 \\
oxalate & $\mathrm{HCl}$ & 4.4 & 18 \\
& $\mathrm{H}_{2} \mathrm{SO}_{4}$ & 55 & 2.2 \\
& $\mathrm{H}_{3} \mathrm{PO}_{4}$ & 67 & 0.56 \\
\hline \multirow{3}{*}{ Brilliant Green oxalate } & $\mathrm{HCl}$ & 4.2 & 19 \\
& $\mathrm{H}_{2} \mathrm{SO}_{4}$ & 82 & 1.4 \\
& $\mathrm{H}_{3} \mathrm{PO}_{4}$ & 68 & 0.56 \\
\hline
\end{tabular}


The dependence of the protective effect of the most efficient inhibitor, $B G$, on its concentration was studied (Figure 1). It was shown that the dependence of $Z$ on $\lg C_{\mathrm{BG}}$ is $S$ shaped. The protective effect of the inhibitor is totally lost at $C_{\mathrm{BG}}=1 \mu \mathrm{M}$, where the $k$ of steel in the presence of the inhibitor becomes equal to that in $2 \mathrm{M} \mathrm{HCl}$ containing only ethanol.

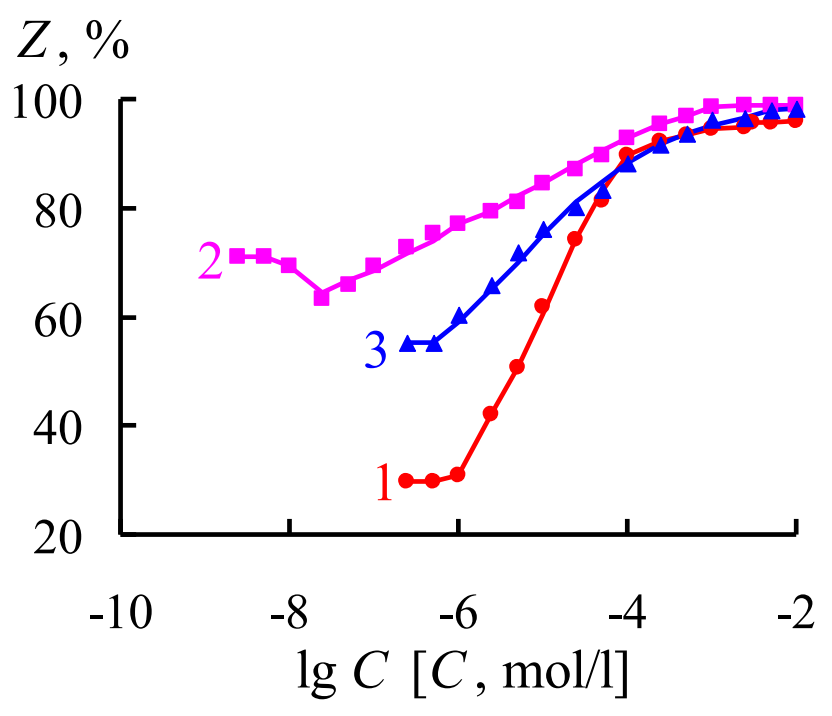

Figure 1. Degree of protection of St3 steel in $2 \mathrm{M} \mathrm{HCl}(1), 2 \mathrm{M} \mathrm{H}_{2} \mathrm{SO}_{4}+0.5 \mathrm{mM} \mathrm{KNCS} \mathrm{(2),}$ and $2 \mathrm{M} \mathrm{H}_{3} \mathrm{PO}_{4}+0.5 \mathrm{mM} \mathrm{KNCS}(3)$ in the presence of Brilliant Green, $t=60^{\circ} \mathrm{C}$.

It was shown that addition of $3.0 \mathrm{mM} \mathrm{BG}$ to the solution can efficiently inhibit steel corrosion up to $60^{\circ} \mathrm{C}$ only (Table 3 ). Its equimolar mixture with urotropine, which is inferior to $\mathrm{BG}$ in protective effect if used alone, especially in hot solutions, is more interesting. The mixture of $3.0 \mathrm{mM} \mathrm{BG}+3.0 \mathrm{mM}$ urotropine is efficient in corrosion inhibition up to $80^{\circ} \mathrm{C}$ inclusive. At $95^{\circ} \mathrm{C}$, addition of $6.0 \mathrm{mM} \mathrm{BG}+6.0 \mathrm{mM}$ urotropine provides $k=8.0 \mathrm{~g} /\left(\mathrm{m}^{2} \cdot \mathrm{h}\right)$ for steel, thus corrosion slows down 130 -fold.

In $2 \mathrm{M} \mathrm{H}_{2} \mathrm{SO}_{4}$, the coefficients of steel corrosion inhibition by the triphenylmethanes studied are considerably lower than in $\mathrm{HCl}$ solutions. In $2 \mathrm{M} \mathrm{H}_{3} \mathrm{PO}_{4}$, even corrosion stimulation is observed (Table 1). This situation is typical of organic corrosion inhibitors. Many compounds (unsaturated compounds [33, 34], azomethines [35], derivatives of triazoles [36] and tetrazoles [37]), which efficiently inhibit steel corrosion in hydrochloric acid solutions, are poor corrosion inhibitors or even stimulate corrosion in $\mathrm{H}_{2} \mathrm{SO}_{4}$ and/or $\mathrm{H}_{3} \mathrm{PO}_{4}$ solutions. A versatile method to improve the inhibitive properties of organic compounds in these media is to create mixed inhibitors on their basis by combining them with sulfur-containing compounds, e.g., KNCS [38]. Addition of $0.5 \mathrm{mM}$ KNCS to $2 \mathrm{M}$ $\mathrm{H}_{2} \mathrm{SO}_{4}$ or $\mathrm{H}_{3} \mathrm{PO}_{4}$ containing $1.0 \mathrm{mM}$ triphenylmethane derivatives better inhibits steel corrosion than solutions without this additive (Table 4). The strongest inhibition of steel 
corrosion is observed in solutions containing $1.0 \mathrm{mM}$ Malachite Green $+0.5 \mathrm{mM} \mathrm{KNCS}$ and especially $1.0 \mathrm{mM} \mathrm{BG}+0.5 \mathrm{mM}$ KNCS.

Table 3. Corrosion rates $(k)$ of $\mathrm{St} 3$ steel and corrosion inhibition coefficients $(\gamma)$ in $2 \mathrm{M}$ solutions of acids in the presence of Brilliant Green and formulations on its basis.

\begin{tabular}{|c|c|c|c|c|c|c|}
\hline \multirow{2}{*}{ Inhibitor } & \multirow{2}{*}{$k, \gamma$} & \multicolumn{5}{|c|}{ Temperature, ${ }^{\circ} \mathrm{C}$} \\
\hline & & 25 & 40 & 60 & 80 & 95 \\
\hline \multicolumn{7}{|c|}{$\mathrm{HCl}$} \\
\hline- & $k$ & 6.4 & 21 & 81 & 406 & 1030 \\
\hline \multirow{2}{*}{$3.0 \mathrm{mM} \mathrm{BG}$} & $k$ & 0.30 & 1.0 & 3.6 & 13 & 33 \\
\hline & $\gamma$ & 21 & 21 & 23 & 31 & 31 \\
\hline \multirow{2}{*}{$3.0 \mathrm{mM}$ urotropine } & $k$ & 1.2 & 2.2 & 6.2 & 133 & 357 \\
\hline & $\gamma$ & 5.3 & 9.5 & 13 & 3.1 & 2.9 \\
\hline \multirow{2}{*}{$\begin{array}{c}1.5 \mathrm{mM} \mathrm{BG} \\
+1.5 \mathrm{mM} \text { urotropine }\end{array}$} & $k$ & 0.60 & 1.2 & 1.9 & 12 & 39 \\
\hline & $\gamma$ & 11 & 18 & 43 & 33 & 26 \\
\hline \multirow{2}{*}{$\begin{array}{c}3.0 \mathrm{mM} \mathrm{BG} \\
+3.0 \mathrm{mM} \text { urotropine }\end{array}$} & $k$ & - & - & - & 5.7 & 15 \\
\hline & $\gamma$ & - & - & - & 71 & 69 \\
\hline \multicolumn{7}{|c|}{$\mathrm{H}_{2} \mathrm{SO}_{4}$} \\
\hline- & $k$ & 17 & 49 & 117 & 366 & 1030 \\
\hline \multirow{2}{*}{$\begin{array}{c}2.5 \mathrm{mM} \mathrm{BG} \\
+0.5 \mathrm{mM} \mathrm{KNCS}\end{array}$} & $k$ & 0.36 & 0.70 & 1.5 & 4.9 & 8.9 \\
\hline & $\gamma$ & 47 & 70 & 78 & 69 & 120 \\
\hline \multicolumn{7}{|c|}{$\mathrm{H}_{3} \mathrm{PO}_{4}$} \\
\hline- & $k$ & 5.8 & 20 & 38 & 141 & 519 \\
\hline \multirow{2}{*}{$\begin{aligned} & 2.5 \mathrm{mM} \mathrm{BG} \\
+ & 0.5 \mathrm{mM} \mathrm{KNCS}\end{aligned}$} & $k$ & 0.50 & 0.66 & 1.3 & 5.0 & 18 \\
\hline & $\gamma$ & 12 & 30 & 29 & 28 & 29 \\
\hline
\end{tabular}

In $2 \mathrm{M} \mathrm{H}_{2} \mathrm{SO}_{4}+0.5 \mathrm{mM} \mathrm{KNCS}$ and $2 \mathrm{M} \mathrm{H}_{3} \mathrm{PO}_{4}+0.5 \mathrm{mM} \mathrm{KNCS}$, the dependence of $Z$ on $\lg C_{\mathrm{BG}}$, like in $\mathrm{HCl}$, has an $S$-shape. The protective effect of the inhibitor in these acids is totally lost at $C_{\mathrm{BG}}=0.25$ and $0.5 \mu \mathrm{M}$, where the $k$ of steel in the presence of BG becomes equal to that in $2 \mathrm{M}$ acids containing only $1.2 \mathrm{M}$ ethanol and $0.5 \mathrm{mM} \mathrm{KNCS}$.

In $2 \mathrm{M} \mathrm{H}_{2} \mathrm{SO}_{4}$, the formulation of $2.5 \mathrm{mM} \mathrm{BG}+0.5 \mathrm{mM} \mathrm{KNCS}$ efficiently inhibits steel corrosion up to $95^{\circ} \mathrm{C}$, with the $k$ not exceeding $8.9 \mathrm{~g} /\left(\mathrm{m}^{2} \cdot \mathrm{h}\right)$. In $2 \mathrm{M} \mathrm{H}_{3} \mathrm{PO}_{4}$, the same mixture considerably inhibits steel corrosion at temperatures up to $80^{\circ} \mathrm{C}$. The formulation of $5.0 \mathrm{mM} \mathrm{BG}+0.5 \mathrm{mM} \mathrm{KNCS}$ at $t=95^{\circ} \mathrm{C}$ inhibits steel corrosion 430 -fold, down to $k=$ $1.2 \mathrm{~g} /\left(\mathrm{m}^{2} \cdot \mathrm{h}\right)$. 
Table 4*. Corrosion rates $(k)$ of St3 steel and corrosion inhibition coefficients $(\gamma)$ in 2 M solutions of acids $+0.5 \mathrm{mM} \mathrm{KNCS}$ in the presence of $1.0 \mathrm{mM}$ triphenylmethane derivatives $\left(60^{\circ} \mathrm{C}\right)$.

\begin{tabular}{cccc}
\hline Inhibitor & Acid & $\boldsymbol{k}, \mathbf{g} /\left(\mathbf{m}^{2} \cdot \mathbf{h}\right)$ & $\boldsymbol{\gamma}$ \\
\hline- & $\mathrm{H}_{2} \mathrm{SO}_{4}$ & $34^{* *}$ & 3.4 \\
& $\mathrm{H}_{3} \mathrm{PO}_{4}$ & $17^{* *}$ & 2.2 \\
\hline \multirow{2}{*}{ Fuchsine } & $\mathrm{H}_{2} \mathrm{SO}_{4}$ & 7.0 & 17 \\
& $\mathrm{H}_{3} \mathrm{PO}_{4}$ & 3.8 & 10 \\
\hline \multirow{2}{*}{ Methyl Violet 2B } & $\mathrm{H}_{2} \mathrm{SO}_{4}$ & 6.8 & 17 \\
\hline \multirow{2}{*}{ Malachite Green } & $\mathrm{H}_{3} \mathrm{PO}_{4}$ & 3.3 & 12 \\
oxalate & $\mathrm{H}_{2} \mathrm{SO}_{4}$ & 2.3 & 51 \\
\hline \multirow{2}{*}{ Brilliant Green oxalate } & $\mathrm{H}_{3} \mathrm{PO}_{4}$ & 1.5 & 25 \\
\hline
\end{tabular}

* The corrosion rates of St3 steel in $2 \mathrm{M} \mathrm{H}_{2} \mathrm{SO}_{4}$ and $\mathrm{H}_{3} \mathrm{PO}_{4}$ are 117 and $38 \mathrm{~g} /\left(\mathrm{m}^{2} \cdot \mathrm{h}\right)$, respectively.

** Data obtained in solutions containing 1.2 M ethanol are reported.

Steel corrosion in $2 \mathrm{M} \mathrm{H}_{2} \mathrm{SO}_{4}$ and $\mathrm{H}_{3} \mathrm{PO}_{4}\left(t=60^{\circ} \mathrm{C}\right)$ can also be inhibited using formulations of $\mathrm{BG}$ with sulfur-containing molecular additives such as thiourea (TU) or its derivatives: phenylthiourea (PTU), tolylthiourea (TTU), and diphenylthiourea (DPTU) (Figure 2). The protective effect of formulations of BG with TU and its substituted derivatives on steel corrosion decreases in the series: DPTU $>$ TTU $>$ PTU $>$ TU, which can be explained by a decrease in the hydrophobicity of the molecules of sulfur-containing compounds in this series. This follows from the correlation between the hydrophobicity of these compounds characterized by the logarithm of their distribution coefficients in the octanol/water system* and the coefficients of steel corrosion inhibition by the individual compounds and their mixtures with BG. Apparently, hydrophobization of steel surface with these compounds facilitates adsorption of the relatively hydrophobic BG inhibitor on the surface and hence enhances corrosion inhibition. The more hydrophobic a TU derivative is, the more strongly it modifies the metal surface and enhances the adsorption of BG. It should be noted that in $2 \mathrm{M} \mathrm{H}_{2} \mathrm{SO}_{4}$ at rather high concentrations of $\mathrm{TU}$ derivatives in the solution $(0.5 \mathrm{mM})$, an antagonism of action of the components of inhibitor mixtures is observed. As a result, the $k$ of steel in the presence of $0.5 \mathrm{mM}$ of a TU derivative is lower than in the presence of $1.0 \mathrm{mM} \mathrm{BG}+0.5 \mathrm{mM}$ TU derivative. However, the $\gamma-\lg D$ plots remain linear in these cases.

${ }^{*}$ Calculated using ACD/ChemSketch software. 


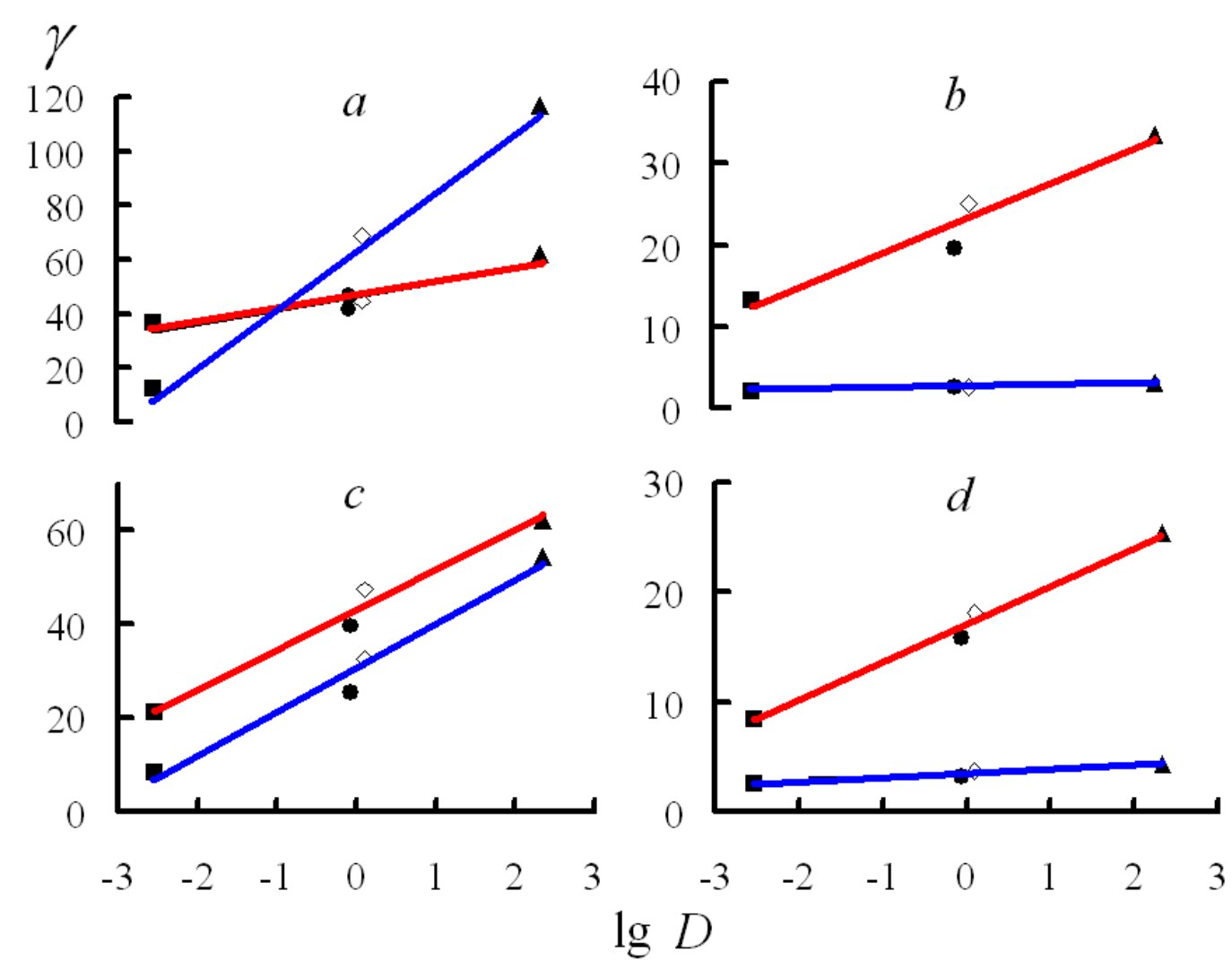

Figure 2. Plots of the degree of protection of St3 steel in $2.0 \mathrm{M} \mathrm{H}_{2} \mathrm{SO}_{4}(a, b)$ and $\mathrm{H}_{3} \mathrm{PO}_{4}(c, d)$ by TU derivatives (-) and their mixtures with $1 \mathrm{mM}$ Brilliant Green (-) on the distribution coefficient of these compounds on octanol/water system at $\mathrm{pH} 0$. Content of TU derivatives, mM: $0.5-a$ and $c, 0.05-b$ and $d$. - TU, - PTU, $\diamond-$ TTU, $\boldsymbol{\Delta}-$ DPTU. $t=60^{\circ} \mathrm{C}$.

\section{Electrochemical studies}

To understand the nature of the protective effects of BG and formulations on its basis, we estimated their effect on the electrode reactions on St3 steel in solutions of mineral acids.

In $2 \mathrm{M} \mathrm{HCl}\left(25^{\circ} \mathrm{C}\right)$, corrosion of St3 steel occurs in the active dissolution region (Figure 3, Table 5). The slope of the cathodic polarization curve of steel was $0.12 \mathrm{~V}$ and the anodic slope was $0.06 \mathrm{~V}$. These slopes are in good agreement with the values predicted by theory [40].

In the presence of $3.0 \mathrm{mM} \mathrm{BG}$, the corrosion potential of steel $\left(E_{\mathrm{cor}}\right)$ is more positive than in the background solution, which indicates that the mixture predominantly hinders the anodic reaction. In this case, the inhibitor being studied slows down both electrode reactions on the metal. It considerably increases the slopes of the cathodic and anodic polarization curves up to the limiting currents, which may suggest that it forms a protective film on steel in $\mathrm{HCl}$ solutions. As concerns the effect of $\mathrm{BG}$ on the electrode reactions, it is similar to that of its equimolar mixture with urotropine, though urotropine itself hinders the electrode reactions only at low cathodic and high anodic potentials and at considerable "distance" from $E_{\text {cor }}$. 


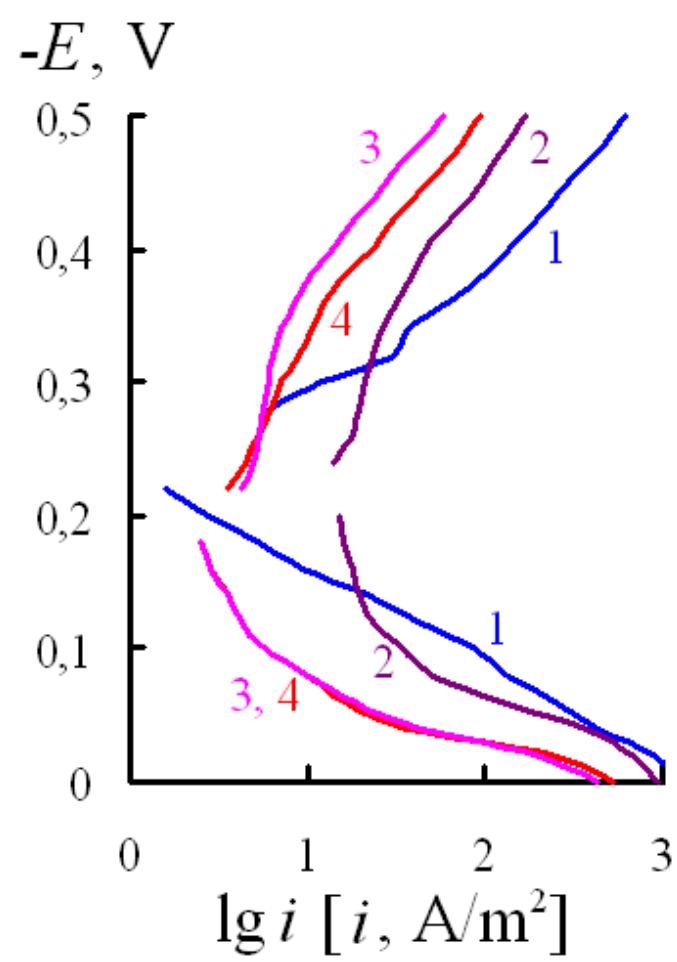

Figure 3. Polarization curves of St3 steel in $2 \mathrm{M} \mathrm{HCl}(1)$ and with additives: $2-3.0 \mathrm{mM}$ urotropine, $3-3.0 \mathrm{mM} \mathrm{BG}, 4-1.5 \mathrm{mM} \mathrm{BG}+1.5 \mathrm{mM}$ urotropine. $t=25^{\circ} \mathrm{C}$.

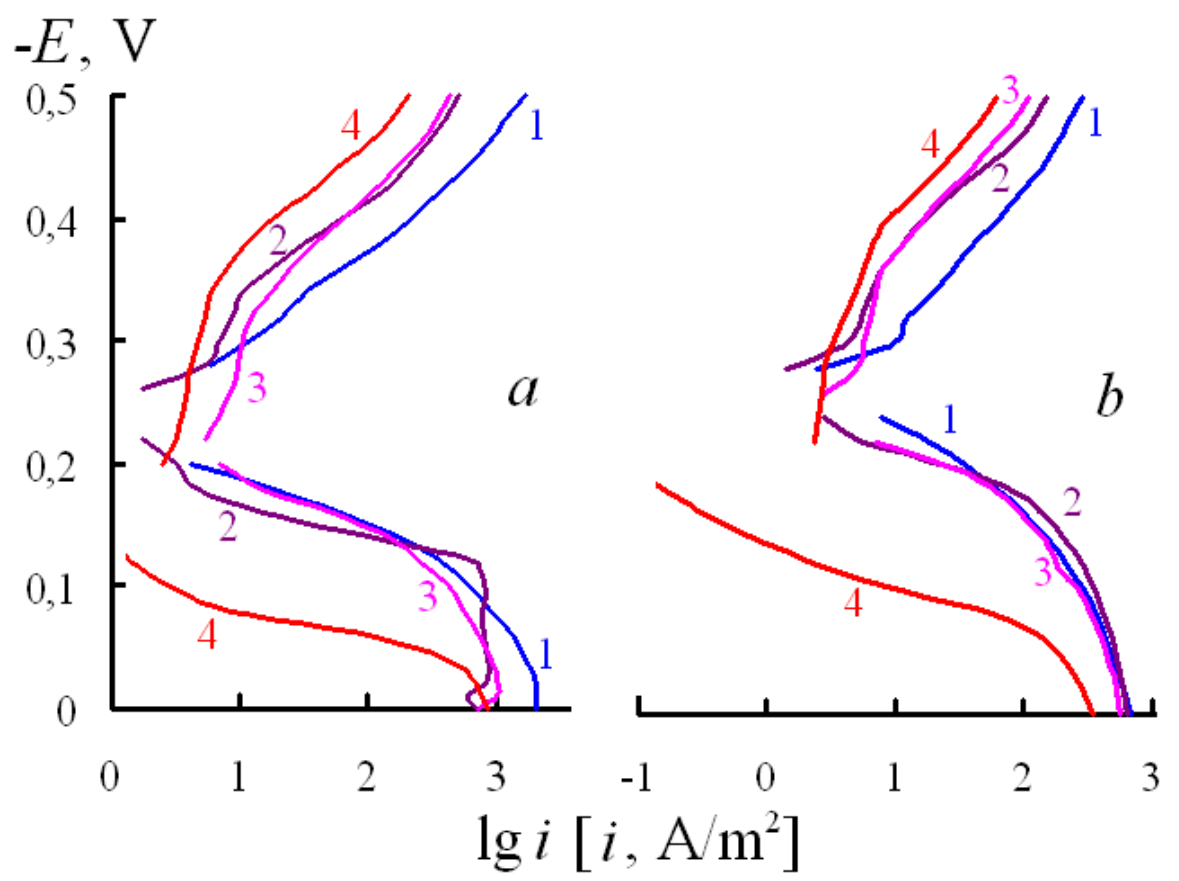

Figure 4. Polarization curves of St3 steel (1) in $2 \mathrm{M} \mathrm{H}_{2} \mathrm{SO}_{4}(a)$ and $\mathrm{H}_{3} \mathrm{PO}_{4}(b)$ and with additives: $2-3.0 \mathrm{mM} \mathrm{KNCS,} 3-3.0 \mathrm{mM} \mathrm{BG}, 4-2.5 \mathrm{mM} \mathrm{BG}+0.5 \mathrm{mM} \mathrm{KNCS} . t=25^{\circ} \mathrm{C}$. 
Table 5. Free corrosion potentials $\left(E_{\text {cor }}\right)$, Tafel slopes $b_{\mathrm{c}}$ and $b_{\mathrm{a}}$, cathodic and anodic current densities $\left(i_{\mathrm{c}}\right.$ and $i_{\mathrm{a}}$ ), and inhibition coefficients for the cathodic and anodic reactions ( $\gamma_{\mathrm{c}}$ and $\left.\gamma_{\mathrm{a}}\right)$ of a steel cylinder in solutions of mineral acids at $E=-0.30$ and $-0.10 \mathrm{~V}$, respectively. $t=25^{\circ} \mathrm{C}$.

\begin{tabular}{|c|c|c|c|c|c|c|c|}
\hline Inhibitor & $E_{\text {cor }}, \mathrm{V}$ & $b_{\mathrm{c}}^{*}, \mathrm{~V}$ & $b_{\mathrm{a}}^{*}, \mathbf{V}$ & $i_{\mathrm{c}}, \mathbf{A} / \mathbf{m}^{2}$ & $i_{\mathrm{a}}, \mathbf{A} / \mathbf{m}^{2}$ & $\gamma_{\mathrm{c}}$ & $\gamma_{\mathrm{a}}$ \\
\hline \multicolumn{8}{|c|}{$2 \mathrm{M} \mathrm{HCl}$} \\
\hline- & -0.24 & 0.12 & 0.06 & 12.2 & 85.4 & - & - \\
\hline $3.0 \mathrm{mM} \mathrm{BG}$ & -0.21 & $i_{\lim } * *$ & $i_{\lim }$ & 6.1 & 5.7 & 2.0 & 15 \\
\hline $3.0 \mathrm{mM}$ urotropine & -0.22 & $i_{\lim }$ & $i_{\lim }$ & 22.4 & 33.9 & 0.54 & 2.5 \\
\hline $\begin{array}{c}1.5 \mathrm{mM} \mathrm{BG}+1.5 \mathrm{mM} \\
\text { urotropine }\end{array}$ & -0.20 & $i_{\lim }$ & $i_{\lim }$ & 7.1 & 5.7 & 1.7 & 15 \\
\hline \multicolumn{8}{|c|}{$2 \mathrm{M} \mathrm{H}_{2} \mathrm{SO}_{4}$} \\
\hline- & -0.23 & 0.10 & 0.04 & 12.2 & 617 & - & - \\
\hline $3.0 \mathrm{mM} \mathrm{BG}$ & -0.21 & $i_{\lim }$ & 0.04 & 10.7 & 414 & 1.1 & 1.5 \\
\hline $3.0 \mathrm{mM} \mathrm{KNCS}$ & -0.23 & $i_{\lim }$ & 0.10 & 7.1 & 798 & 1.7 & 0.77 \\
\hline $2.5 \mathrm{mM} \mathrm{BG}+0.5 \mathrm{mM} \mathrm{KNCS}$ & -0.17 & $i_{\lim }$ & 0.12 & 4.8 & 2.9 & 2.5 & 213 \\
\hline \multicolumn{8}{|c|}{$2 \mathrm{M} \mathrm{H}_{3} \mathrm{PO}_{4}$} \\
\hline- & -0.25 & 0.10 & 0.08 & 9.8 & 291 & - & - \\
\hline $3.0 \mathrm{mM} \mathrm{BG}$ & -0.25 & $i_{\lim }$ & 0.04 & 5.7 & 271 & 1.7 & 1.1 \\
\hline $3.0 \mathrm{mM} \mathrm{KNCS}$ & -0.26 & $i_{\text {lim }}$ & 0.04 & 4.3 & 363 & 2.3 & 0.80 \\
\hline $2.5 \mathrm{mM} \mathrm{BG}+0.5 \mathrm{mM} \mathrm{KNCS}$ & -0.21 & $i_{\lim }$ & 0.06 & 3.2 & 11.3 & 3.1 & 26 \\
\hline
\end{tabular}

* The reported values correspond to the first linear part of the cathodic or anodic polarization curve.

$* * i_{\text {lim }}-$ limiting current.

Like in hydrochloric acid medium, St 3 in $2 \mathrm{M} \mathrm{H}_{2} \mathrm{SO}_{4}$ and $\mathrm{H}_{3} \mathrm{PO}_{4}$ at $25^{\circ} \mathrm{C}$ is in active state (Figure 4, Table 5). In $2 \mathrm{M} \mathrm{H}_{2} \mathrm{SO}_{4}$, the slope of the cathodic polarization curve is close to $0.10 \mathrm{~V}$ and that of the anodic curve is close to $0.04 \mathrm{~V}$, in agreement with the theoretically predicted values [40]. In $2 \mathrm{M} \mathrm{H}_{3} \mathrm{PO}_{4}$, the slope of steel cathodic polarization agrees with the theory $(0.10 \mathrm{~V})$. However, the anodic process is characterized by a higher slope of $0.08 \mathrm{~V}$, which apparently results from the formation of a sludge layer on the steel surface during the 30-minute electrode exposure at $E_{\text {cor }}$ followed by its anodic polarization [41].

In both acids, addition of $3.0 \mathrm{mM} \mathrm{BG}$ weakly inhibits the electrode reactions of steel. They are affected more considerably by the mixture of $2.5 \mathrm{mM} \mathrm{BG}+0.5 \mathrm{mM}$ KNCS, which predominantly slows down the anodic process, as indicated by the shift in $E_{\text {cor }}$ of steel towards more positive potentials in comparison with the background solutions. The formulation being studied considerably inhibits both anodic and cathodic reactions on steel. The presence of the mixture of $2.5 \mathrm{mM} \mathrm{BG}+0.5 \mathrm{mM}$ KNCS increases the slopes of 
steel cathodic polarization in $2 \mathrm{M} \mathrm{H}_{2} \mathrm{SO}_{4}$ and $\mathrm{H}_{3} \mathrm{PO}_{4}$ up to the limiting current, which, as noted above, may result from the formation of a protective film from inhibitor components on the metal. Addition of KNCS alone inhibits the cathodic process more weakly than its mixture with $\mathrm{BG}$, and also stimulates the anodic reaction.

A qualitative agreement between the corrosion and electrochemical data is observed. The results obtained show that the good efficiency of the protective mixtures we developed on the basis of BG in the inhibition of low-carbon steel corrosion results from the strong hindrance of the metal electrode reactions in solutions of mineral acids.

Thus, based on Brilliant Green, an available pharmaceutical compound, we have developed composite inhibitors that provide efficient protection of low carbon steel in solutions of mineral acids $\left(\mathrm{HCl}, \mathrm{H}_{2} \mathrm{SO}_{4}\right.$ and $\left.\mathrm{H}_{3} \mathrm{PO}_{4}\right)$ in a broad temperature range $(25-$ $95^{\circ} \mathrm{C}$ ). The composite inhibitors we proposed principally differ from the medical compounds described in literature which were studied as steel corrosion inhibitors and demonstrated protective effects only in cold solutions.

\section{Conclusions}

1. Of amines belonging to the triphenylmethane series (fuchsine, Methyl Violet, Malachite Green and Brilliant Green), Brilliant Green, both alone and in mixtures, has the highest protective effect on the corrosion of St3 steel in mineral acids.

2. It can be recommended to protect steel in mineral acid solutions at temperatures up to $95^{\circ} \mathrm{C}$ using formulations of Brilliant Green with urotropine $(\mathrm{HCl})$ or with $\mathrm{KNCS}\left(\mathrm{H}_{2} \mathrm{SO}_{4}\right.$ and $\mathrm{H}_{3} \mathrm{PO}_{4}$ ).

3. In protection of steel in $\mathrm{H}_{2} \mathrm{SO}_{4}$ and $\mathrm{H}_{3} \mathrm{PO}_{4}$ solutions by formulations of Brilliant Green with thiourea derivatives, a linear correlation was noted between the coefficients of steel inhibition by these mixtures and the hydrophobicity of the sulfur-containing molecules they contain.

4. The high protective effect of the inhibitor formulations developed on the basis of Brilliant Green on steel corrosion in mineral acid solutions results from efficient inhibition of the electrode reactions on the metal by these compounds.

\section{References}

1. Indicators, 1st Edition, ed. E. Bishop, Pergamon Press, Oxford, New York, Toronto, Sydney, Braunschweig, 1972, 756 pp.

2. M.D. Mashkovsky, Lekarstvennye sredstva (Medicinal products), 16th Edition, Novaya Volna, Moscow, 2012, 1216 pp. (in Russian).

3. O.N. Bauer, V.A. Musselius and Yu.A. Strelkov, Bolezni prudovykh ryb (Diseases of pond fish), Kolos, Moscow, 1969, pp. 126-128 (in Russian).

4. A.I. Altsibeeva and S.Z. Levin, Ingibitory korrozii metallov. Spravochnik (Metal Corrosion Inhibitors. Handbook), Khimiya, Leningrad, 1968, pp. 7-82 (in Russian). 
5. Ya.G. Avdeev, D.S. Kuznetsov, M.V. Tyurina, S.V. Oleynik and M.A. Chekulaev, Int. J. Corros. Scale Inhib., 2017, 6, no. 1, 47. doi: 10.17675/2305-6894-2017-6-1-4

6. Ya.G. Avdeev, D.S. Kuznetsov M.V. Tyurina, S.V. Oleynik and M.A. Chekulaev, Int. J. Corros. Scale Inhib., 2017, 6, no. 2, 180. doi: 10.17675/2305-6894-2017-6-2-7

7. G. Gece, Corros. Sci., 2011, 53, 3873. doi: 10.1016/j.corsci.2011.08.006

8. R.K. Pathak and P. Mishra, Int. J. Sci. Res., 2016, 5, no. 4, 671.

9. S. Karthikeyan, Int. J. ChemTech Res., 2016, 9, no. 6, 251.

10. I.A. Adejoro, F.K. Ojo and S.K. Obafemi, J. Taibah Univ. Sci., 2015, 9, 196.

11. S. Hari Kumar and S. Karthikeyan, J. Mater. Environ. Sci., 2012, 3, no. 5, 925.

12. A.S. Fouda, M.A. Elmorsi, T.A. Fayed, A.F. Hassan and M. Soltan, Int. J. Adv. Res., 2014, 2, no. 4, 788.

13. X.H. Pang, M. Gong, Y.X. Zhang, Q. Wei and B.R. Hou, Sci. China Chem., 2011, 54, no. $9,1529$.

14. N.O. Eddy and S.A. Odoemelam, Adv. Nat. Appl. Sci., 2008, 2, no. 3, 225.

15. N.O. Eddy and E.E. Ebenso, Int. J. Electrochem. Sci., 2010, 5, 731.

16. R.J. Aziz, Int. J. Curr. Res. Chem. Pharm. Sci., 2016, 3, no. 12, 1.

17. N.O. Eddy, E.E. Ebenso and U.J. Ibok, J. Appl. Electrochem., 2010, 40, 445.

18. S.K. Shukla and M.A. Quraishi, Corros. Sci., 2009, 51, 1007.

19. A.K. Singh and M.A. Quraishi, Corros. Sci., 2010, 52, 152.

20. S.K. Shukla and M.A. Quraishi, Mater. Chem. Phys., 2010, 120, 142.

21. A.K. Singh, S.K. Shukla, M. Singh and M.A. Quraishi, Mater. Chem. Phys., 2011, 129, 68.

22. M.S. Morad, Corros. Sci., 2008, 50, 436.

23. X.H. Pang, W.J. Guo, W.H. Li, J.D. Xie and B.R. Hou, Sci. China, Ser. B: Chem., 2008, 51, no. 10, 928.

24. M. Sobhi, Prot. Met. Phys. Chem. Surf., 2014, 50, no. 6, 825.

25. M.M. El-Naggar, Corros. Sci., 2007, 49, 2226.

26. T. Arslan, F. Kandemirli, E.E. Ebenso, I. Love and H. Alemu, Corros. Sci., 2009, 51, 35.

27. O.K. Abiola, Corros. Sci., 2006, 48, 3078.

28. R. Solmaz, Corros. Sci., 2014, 81, 75.

29. S. Ananth Kumar, A. Sankar and S. Ramesh Kumar, Int. J. Comput. Eng. Sci., 2013, 3, no. $1,57$.

30. M. Ozcan, R. Solmaz, G. Kardas and I. Dehri, Colloids Surf. A: Physicochem. Eng. Aspects, 2008, 325, 57.

31. Ya.G. Avdeev and M.V. Tyurina, Korroz.: mater., zashch., 2016, no. 2, 7 (in Russian).

32. Ya.G. Avdeev and Yu.I. Kuznetsov, Russ. Chem. Rev., 2012, 81, no. 12, 1133. doi: 10.1070/RC2012v081n12ABEH004292

33. N.I. Podobaev and Ya.G. Avdeev, Prot. Met., 2004, 40, no. 1, 7.

34. Ya.G. Avdeev, Prot. Met. Phys. Chem. Surf., 2015, 51, no. 7, 1140. doi: $\underline{10.1134 / \mathrm{S} 2070205115070023}$ 
35. Ya.G. Avdeev and Yu.I. Kuznetsov, Korroz.: mater., zashch., 2009, no. 12, 4 (in Russian).

36. Ya.G. Avdeev, L.V. Frolova, Yu.I. Kuznetsov and O. O. Zel', Korroz.: mater., zashch., 2010, no. 5, 22 (in Russian).

37. Ya.G. Avdeev, Yu.I. Kuznetsov, V.A. Ostrovskii, M.V. Tyurina, P.A. Aleshunin and O.O. Zel', Korroz.: mater., zashch., 2011, no. 4, 28 (in Russian).

38. Ya.G. Avdeev, Yu.I. Kuznetsov and M.V. Tyurina, Korroz.: mater., zashch., 2012, no. 5, 22 (in Russian).

39. Ya.G. Avdeev, M.V. Tyurina and Yu.I. Kuznetsov, Vestnik Tambovskogo universiteta. Seriya: Estestvennye i tekhnicheskie nauki (Tambov University Reports. Series: Natural and Technical Sciences), 2013, 18, no. 5, 2258 (in Russian).

40. S.M. Reshetnikov, Ingibitory kislotnoi korrozii metallov (Metal Corrosion Inhibitors in Acids), Khimiya, Leningrad, 1986, 144 p. (in Russian).

41. Ya.G. Avdeev and M.V. Tyurina, Korroz.: mater., zashch., 2015, no. 6, 19 (in Russian). 